\title{
Effects of Self-compassion Training on the Positive and Negative Emotions of Nursing Students: A Quasi-experimental Study
}

\author{
Fariba Alirezaee ${ }^{1}$, Marjan Mardani Hamooleh ${ }^{2}$, Naima Seyedfatemi ${ }^{3}$, Mahnaz Ghaljeh ${ }^{4}$, \\ Shima Haghani ${ }^{5}$
}

\begin{abstract}
Background \& Aims: Paying attention to positive and negative emotions is very important and is one of the predictors of happiness and satisfaction in life. When judging the happiness and satisfaction of their lives, some people pay attention to the level of their negative and positive emotions, which indicates that their positive emotions prevail over negative ones. Nursing students experience a range of positive and negative emotions during their studies, and in the meantime, negative emotions and feelings can become more troublesome and hinder their learning. Studies show that emotions students experience in different learning environments can act as facilitators for their academic success, academic adjustment, and psychological well-being. Also, the results of studies show a significant positive relationship between students' positive emotion and their academic achievement. Students who receive compassion-based education have more hope, self-esteem, and overall mental health than their peers. The present study aimed to evaluate the effects of self-compassion training on the positive and negative emotions of nursing students.

Materials \& Methods: This was a quasi-experimental study with pre-test and post-test design, which was conducted on 50 undergraduate nursing students studying at Iran University of Medical Sciences in the second semester of 2020. Inclusion criteria were being a bachelor student, not using psychiatric drugs, no stressful events such as divorce, death of loved ones, etc. in the past four months and a history of attending similar training classes. Exclusion criteria were not answering the exercises for at least 2 sessions. The students were selected through convenience sampling method and took the pretest. Then, students underwent training for eight 60 minute sessions (during one month and for two sessions each week). Some tasks were considered for the students in the interval of two sessions that were held during a week, and the students sent the answers of these exercises individually to the researcher. The students took the posttest one month after the last session. The instruments used were demographic profile and the reliable and valid Positive Affect and Negative Affect Scale (PANAS). Data analysis was performed using SPSS 16 through descriptive statistics (frequency, percentage, mean, and standard deviation) and inferential statistics (paired t-test). In order to comply with ethical considerations, after obtaining permission from the ethics committee of Iran University of Medical Sciences, along with obtaining written consent from the samples, they were told that the information contained in the tools would remain confidential and there would be no obligation to participate in the research.
\end{abstract}

\footnotetext{
1. Department of Psychiatric Nursing, Nursing Care Research Center, School of Nursing and Midwifery, Iran University of Medical Sciences, Tehran, Iran

2. Department of Psychiatric Nursing, Nursing Care Research Center, School of Nursing and Midwifery, Iran University of Medical Sciences, Tehran, Iran (Corresponding author) Tel: 02143651804 Email: mardanihamoole.m@iums.ac.ir

3. Department of Psychiatric Nursing, Nursing Care Research Center, School of Nursing and Midwifery, Iran University of Medical Sciences, Tehran, Iran

${ }^{4}$. Community Nursing Research Center, Department of Nursing Management, Zahedan University of Medical Sciences, Zahedan, Iran

5. Biostatistics, Nursing Care Research Center, Iran University of Medical Sciences, Tehran, Iran
} 
Results: The results of paired t-test showed that the positive emotions of the nursing students in the posttest with a mean score of $37.2 \pm 9.5$ was significantly higher than the pretest with a mean score of $21.24 \pm 2.36$, which indicates the superiority of the numerical indicators of positive emotion $(\mathrm{P}=0.001 ; \mathrm{t}=23.388)$. Also, the results of paired t-test on negative emotions showed that the posttest score $(12.2 \pm 44.5)$ was significantly lower than the pretest score $(20.34 \pm 1.72)$, which indicates the superiority of the numerical indicators of negative emotion of nursing students $(\mathrm{P}<0.001 ; \mathrm{t}=19.89)$. The results indicated that in the posttest, the scores of positive emotions increased significantly in all the time dimensions, while the scores of negative emotions decreased significantly. Conclusion: The results of present study show that self-compassion-based education was effective on reducing negative emotions of nursing students, and therefore, affirm the research hypothesis that self-compassion-based education can increase the positive emotion scores and decrease negative emotion scores in the posttest. Based on the results of the research, self-compassion education can be employed as a high capability method for increasing positive emotions and reducing negative emotions of nursing students. The results of this study are useful for counseling centers of medical universities to better manage counseling for students. In the field of nursing students' education, the self-compassion training content presented in this study can be provided to nursing professors to acquaint their students with this content and these students can use this content as much as possible in their care plans for clients as self-compassion is a concept that applies to both healthy and sick groups in society. It is suggested that similar studies be performed on nursing students in other medical universities of the country and also on other fields of medical sciences to compare their results.

Keywords: Self-compassion Training, Positive Emotions, Negative Emotions, Nursing Students

\section{Conflict of Interest: No}

How to Cite: Alirezaee F, Mardani Hamooleh M, Seyedfatemi N, Ghaljeh M, Haghani SH. Effects of Selfcompassion Training on the Positive and Negative Emotions of Nursing Students: A Quasi-experimental Study. Iran Journal of Nursing. 2021; 34(132):21-32.

Received: 7 Jul 2021

Accepted: 6 Oct 2021 


\title{
تأثير آموزش مبتنى بر خود- شفقتورزى بر عاطفه مثبت و منفى دانشجويان يرستارى: يك مطالعه نيمهتجربى بر
}

\author{
فريبا عليرضايى '، مرجان مردانى حموله '، نعيمه سيدفاطمى '، مهناز قلجهءُ، شيما حقانى
}

زمينه و هدف: توجه به سلامت روانى دانشجويان يرستارى كه بزركترين كروه بهاشداشتى و درمانى را در آينده تشكيل خواهند داد، بسيار حائز اهميت

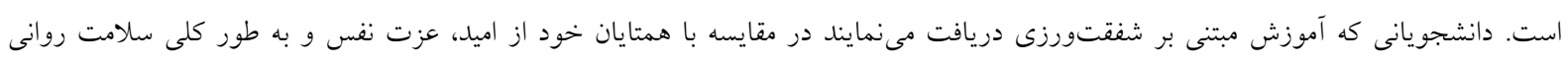

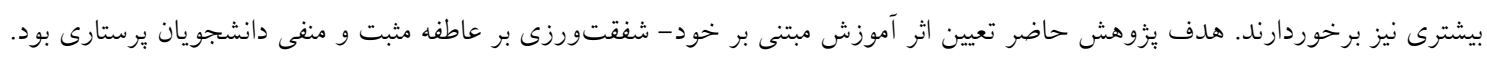

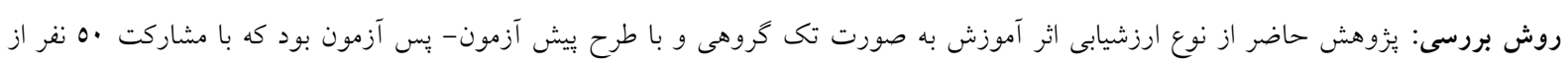

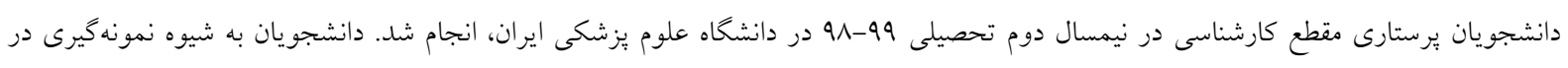

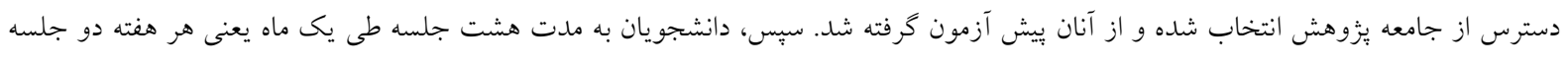

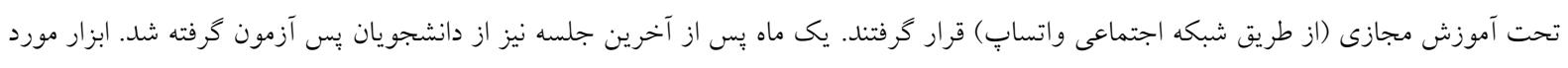

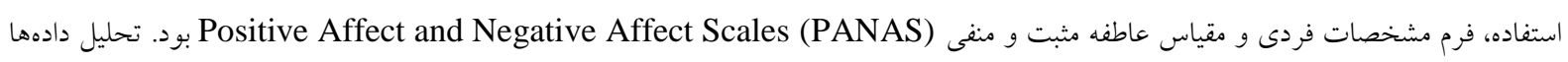

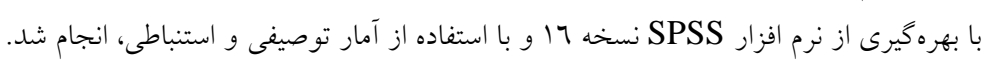

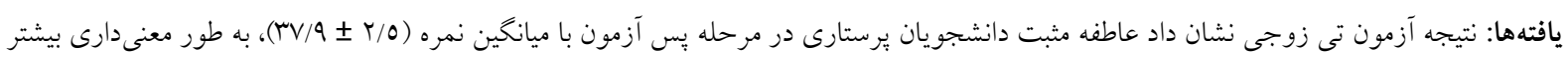

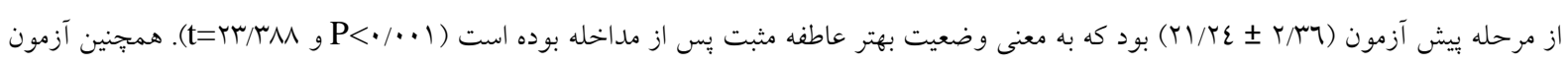

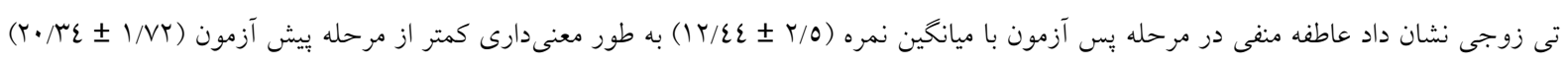

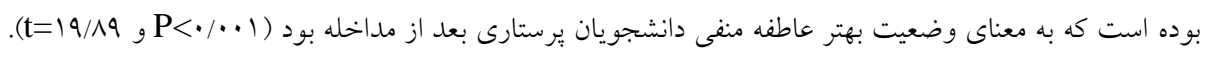

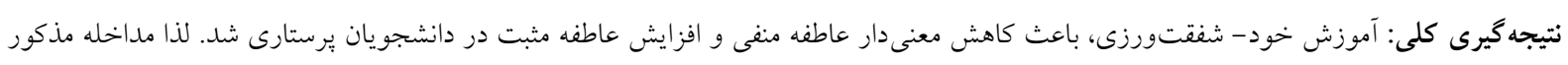

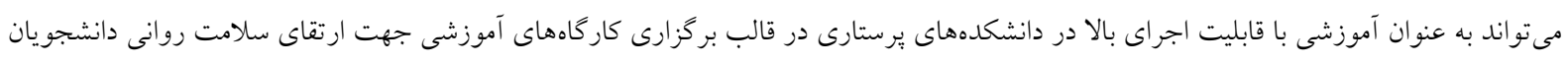
مورد استفاده قرار كيرد.

كليد وازهها: آموزش خود - شفقتورزى، عاطفه مثبت، عاطفه منفى، دانشجوى برستارى

$$
\begin{aligned}
& \text { تعارض منافع: ندارد }
\end{aligned}
$$

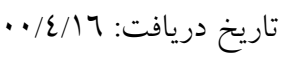

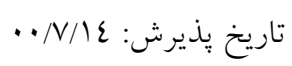

'. يروه روانيرستارى، مر كز تحقيقات مراقبتهاى يرستارى، دانشكده يرستارى و مامايى، دانشكاه علوم يزشكى و خدمات بهداشتى درمانى ايران، تهران،

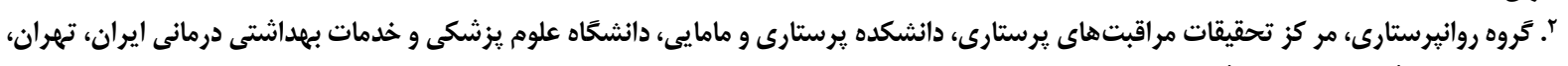

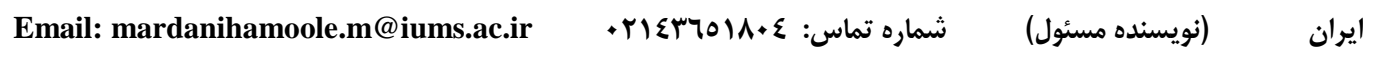

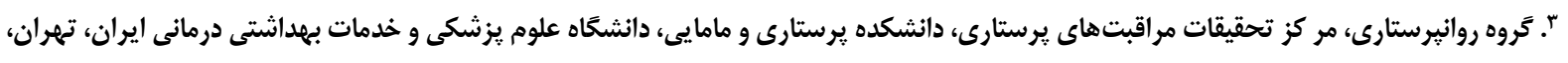

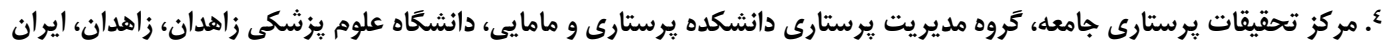

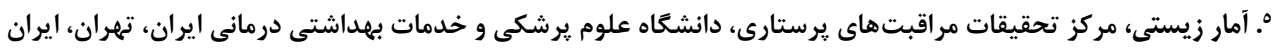


تحصيلى دانشجويان رابطه منفى دارد و منجر به استرس

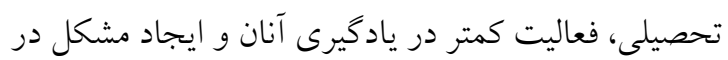

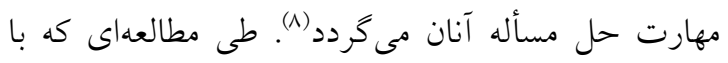

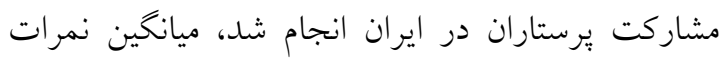

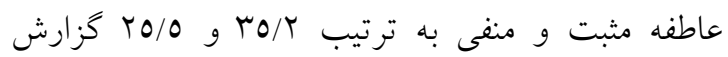

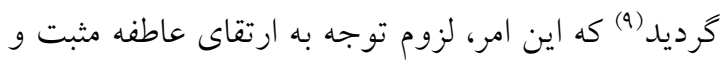
بهبود عاطفه منفى را نمايان مى سازد. در اين ميان، يكى از مفاهيمى كه نقش مهمى در بهبود عواطف افراد دارد، خود- شفقتورزى است. خود- لهاه شفتتورزى بر تنظيم و تعادل هيجانى متمركز است و

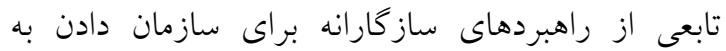

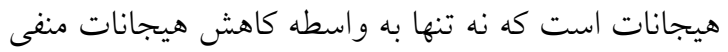
بلكه از طريق ايجاد و خلق هيجانات مثبت از قبيل مهربانى

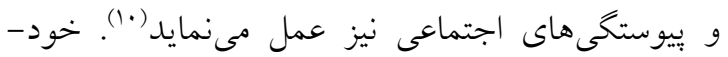

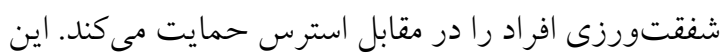
ويزّكى به معناى بذيرش احساسات آسيب يذّير، مراقبت

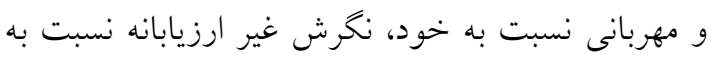

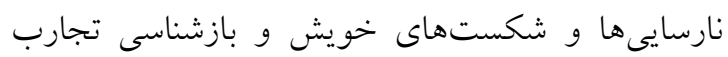

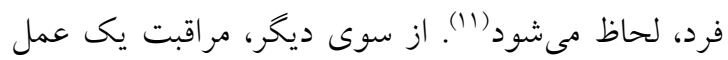
دلسوزانه در برستارى به حساب مى آيد و در در اين ميان

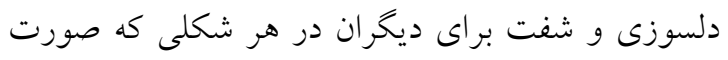
كيرد، مستلزم داشتن خود - شفقتورزى است. با توجه به ديه اين كه جالشهاى موجود در محيطهاى بالينى مى تواند

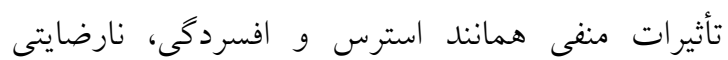
شغلى، نا امنى محيط شغلى و ترى حرفه را به دنبال داشته نئه

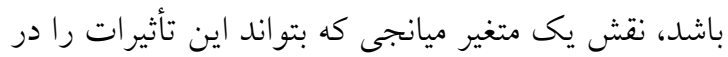
يرستاران كاهش دهد، حائز اهميت است. خود- شفقت ورزى منبع قدرتمند و يك بايه و اصل براى مراقبت دلسوزانه بوده و به يرستاران كمك مىنمايد تا با تجارب تصن و رويدادهاى محيط كارى و زندگى خود، بهتر مواجه

$$
\text { شوند (9) }
$$

هدف از خود- شفقتورزى، تسهيل تغيير عاطفى به منظور مراقبت بيشتر و حمايت از خود است كه انتقاد از

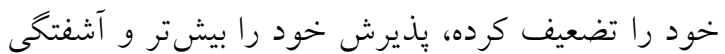

\section{مقدمه}

عواطف از آن جهت براى افراد بشر حائز اهميت است كه فعاليتهاى آنان را به سوى هدفى متوجه مي سازد و و انسان

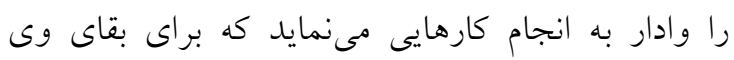

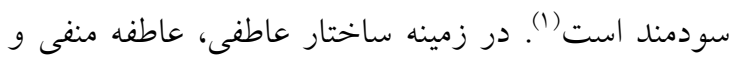
عاطفه مثبت، مدنظر مىباشد (؟). عاطفه مثبت در بر كيرنده

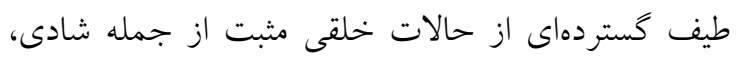
احساس توانمندى، شور و شوق، تمايل، علاقه و عزت

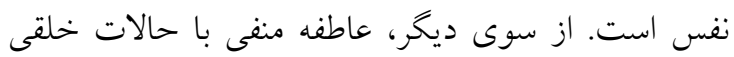
اجتنابى از قبيل خشم، غم، تنفر، حقارت، احساس كُناه،

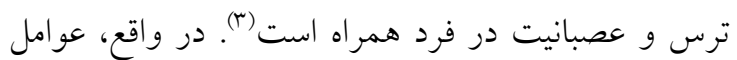
مؤثر بر كاميابى و موفقيت افراد ناشى از احساسات و عواطف مثبتى است كه آنان در خود ايجاد مى كنند. در مقابل، افراد ناموفق كسانى هستند كه احساسات و عواطف منفى را در خود بِرورش مىدهند (ع). از سوى ديخر، توجه به عاطفه مثبت و منفى به عنوان نشانخرهاى كنشورى مثبت و كنشورى منفى از اهميت بالايى برخوردار است و لهون يكى از ييش بينى كنندهاى شادى و رضايتمندى از زندكى به حساب مى آيد. اغلب افراد هنغام قضاوت در

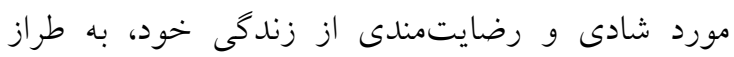
عو اطف منفى و مثبت خود توجه دارند كه نشان دهنده غلبه

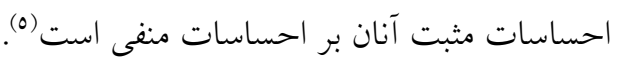
در خصوص شاغلين به تحصيل در رشته بِرستارى، دانشجويان مربوطه در طول تحصيل طيفى از عواطف مثبت و منفى را تجربه مى كنند و در اين ميان احساسات

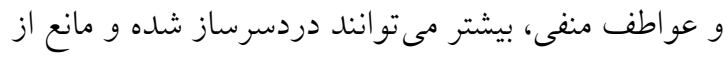

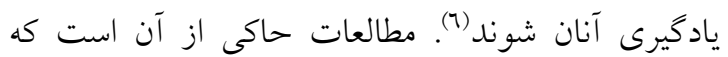
احساساتى كه دانشجويان در محيطهاى مختلف يادگيرى تجربه خواهند كرد، مىتواند به عنوان تسهيل كنندهايى در جهت موفقيت تحصيلى، سازگارى تحصيلى و بهزيستى روانى آنان عمل نمايد. همجنين، نتايج مطالعات نشان مىدهد كه بين عاطفه مثبت و بيشرفت تحصيلى

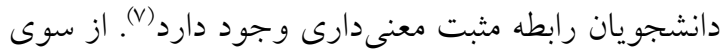
ديكر، مشخص گرديده كه عواطف منفى با عملكرد 
تا يُزوهشى به منظور تعيين اثر آموزش مبتنى بر خود-

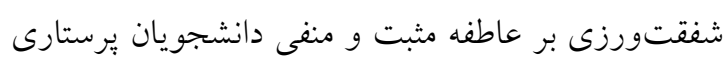

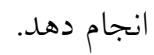

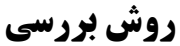

مطالعه حاضر، نيمه تجربى و تكى گروهى با طرح بيش

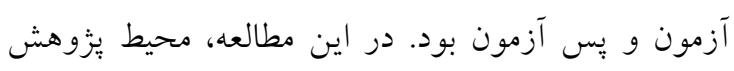

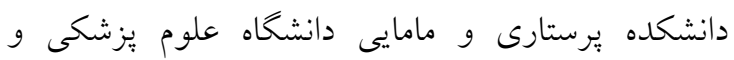

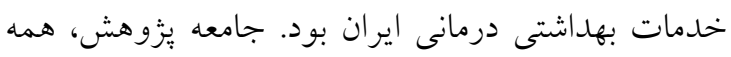
دانشجويان كارشناسى يرستارى شاغل به تحصيل در سال

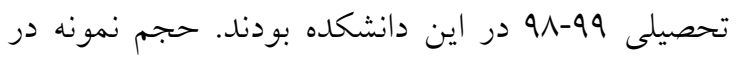

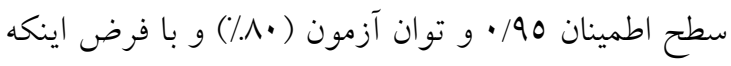

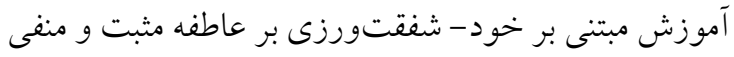

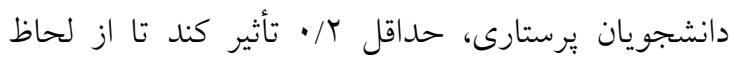
آمارى معنىدار تلقى شود، پِ از از جايخذارى در فرمول

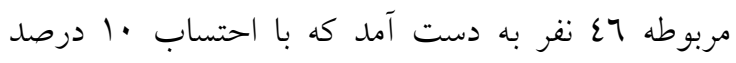

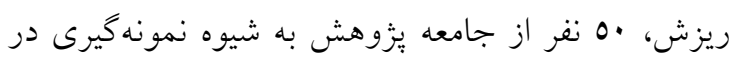

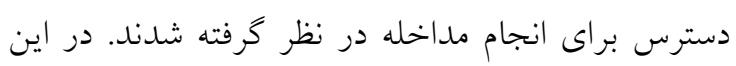
يزوهش ملاكهاى ورود به مطالعه شامل شاغل به تحصيل

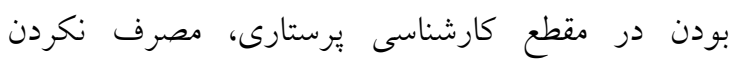

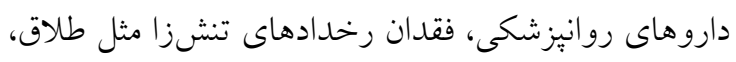

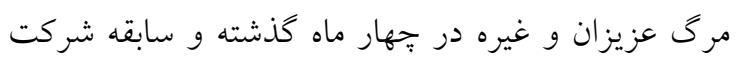

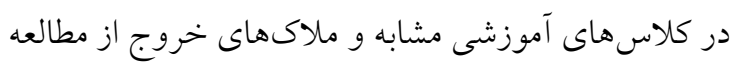

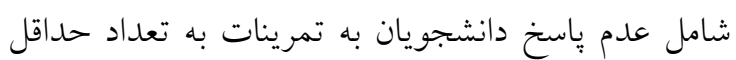

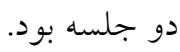
به دليل شيوع كوويد- 19 و امكان بذير نبودن بركزارى جلسات به صورت حضورى، طى مكاتبهاى با واحد

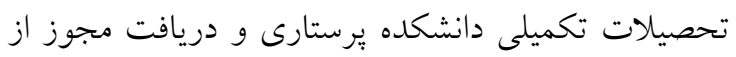

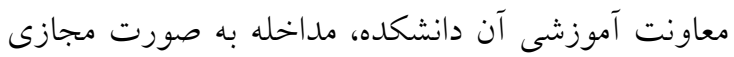

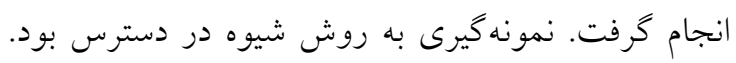

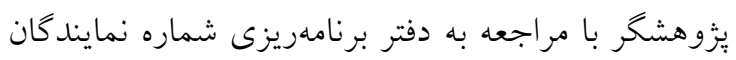

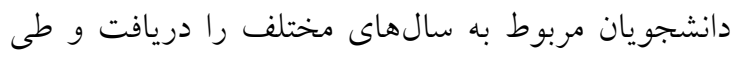

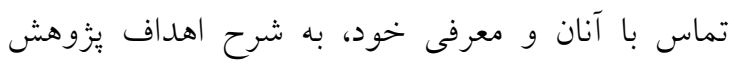

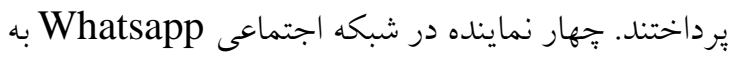

عاطفى را كاهش مى دهد. بنابراين فرد را قادر مى سازد

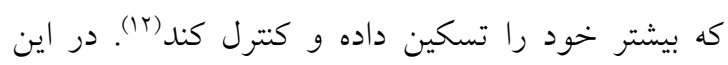
رابطه، آموزش خود - شفقتورزى باعث كاهش مشكلات هيجانى و عواطف منفى افراد مىشود و اجراى مداخله

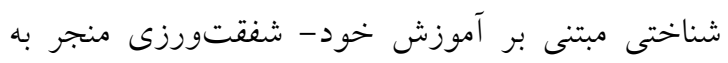

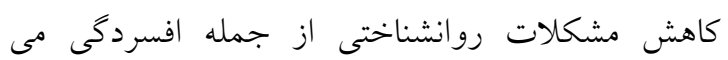

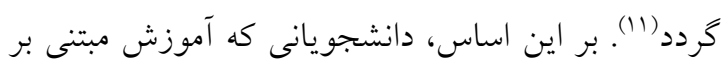
شفقتورزى دريافت مىنمايند، در مقايسه با همتايان خود؛ اميد، حرمت خود، سلامت روانى و عواطف مثبت

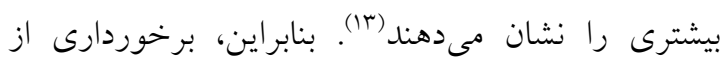
ويزگى خود - شفتتورزى، براى دانشجويان يرستارى نيز حائز اهميت است زيرا نتايج مطالعهاى بر روى دانشجويان

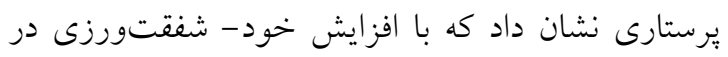
دانشجويان مىتوان عواطف مثبت آنان را افزايش داد.

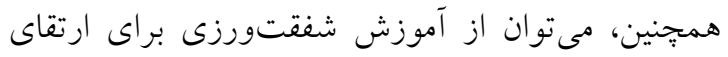
رضايت از زندكى دانشجويان يرستارى بهره برد (ع (1).

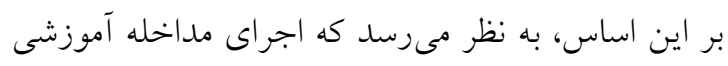

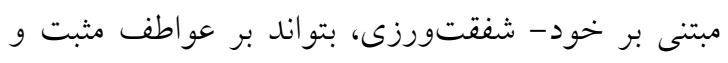

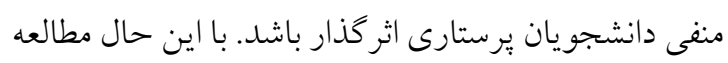

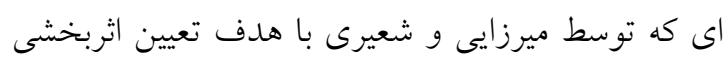

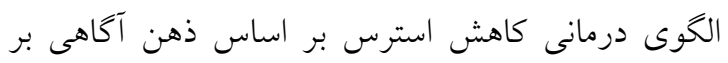
عواطف مثبت و منفى دانشجويان در شهر زنجان انجام

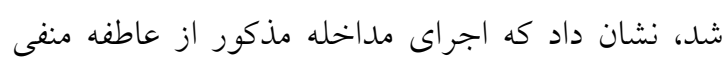

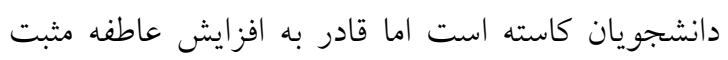

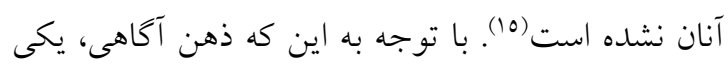

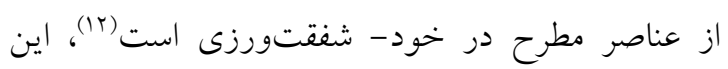
تناقض در يافتهاى يززوهشى، ضرورت اجراى مطالعهاى

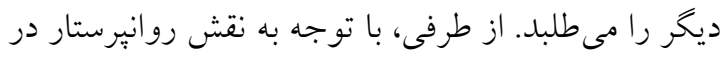

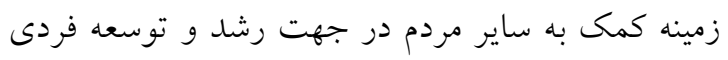

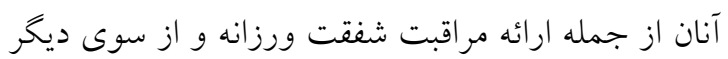
با عنايت به شرايط خاص تحصيلى دانشجويان برستارى

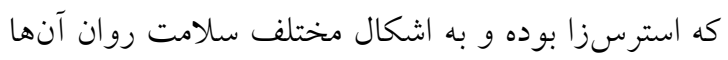

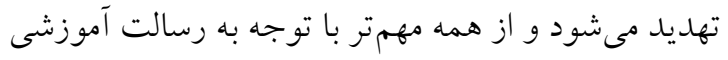

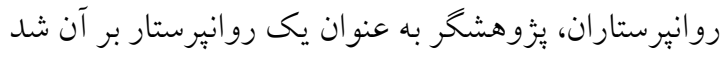


شده بود و به روش سخنرانى توسط يزوهشخر ارائه مى

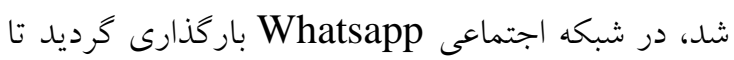

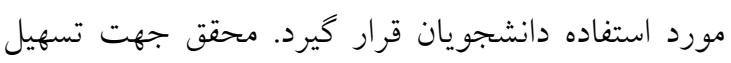

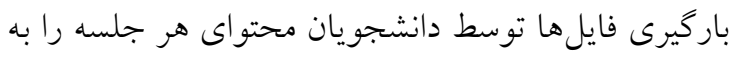

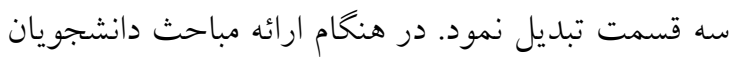

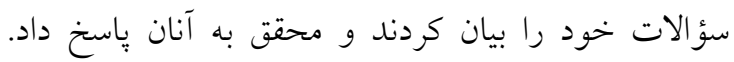
دانشجويانى كه به هر دليل در زمان ارائه مباحث برخط نبودند نيز سؤالات خود را به صورت موردى از محقق لهق يرسيده و جواب دريافت نمودند. محقق براى دانشجويان در فاصله دو جلسه كه طى يك هفته بركزار مىشد، تمريناتى در نظر كرفت و دانشجويان پاسخ اين تمرينات

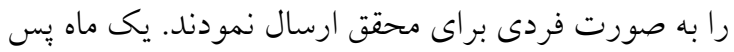
از آخرين جلسه از دانشجويان يس آزمون كرفته شد. خلاصه جلسات آموزشى در جدول شماره إمشهود است.
عنوان مدير گروه براى گروه آموزش خود- شفقتورزى

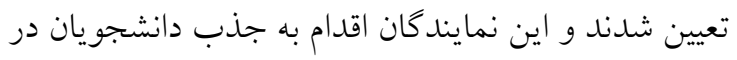

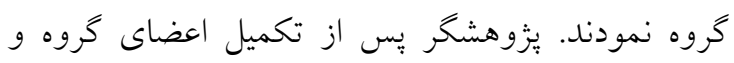

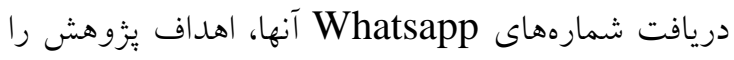

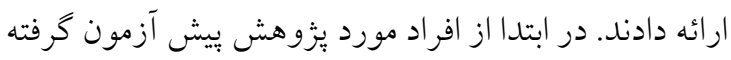
شد. به اين منظور هر جهار نماينده كليه فرمهاى ييش

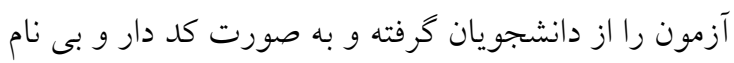
براى يُزوهشخر ايميل نمودند. شايان ذكر است در فرمهاى

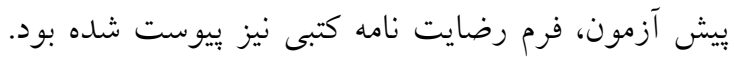
سبس دانشجويان به مدت هشت جلسه ل7 دقيقهاى (به

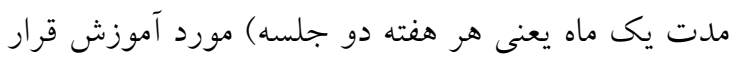

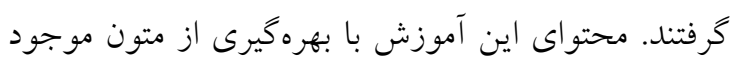
در همين رابطه تهيه شد(11-0) و روايى محتواى آن توسط اساتيد داور بايان نامه و گروه تحقيق تعيين شد. اين محتوا در قالب فايل صوتى و ويديوهايى كه در همين رابطه تهيه

جدول شماره ا: جلسات آموزش مبتنى بر خود- شفقتورزى

\begin{tabular}{|c|c|}
\hline شرح آموزش مبتنى بر خود- شفقتورزى & جلسات \\
\hline 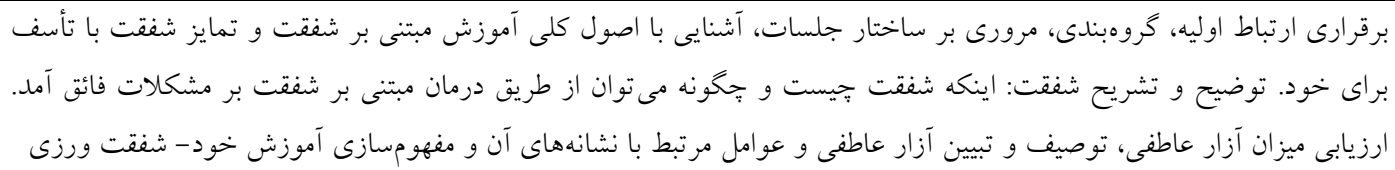 & 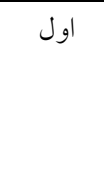 \\
\hline
\end{tabular}

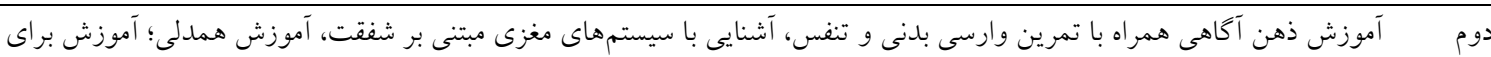

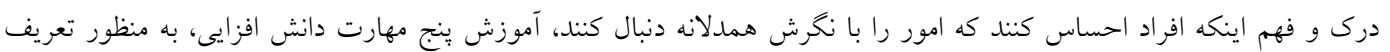

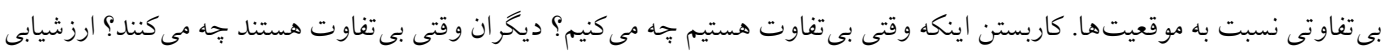

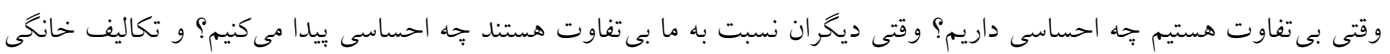

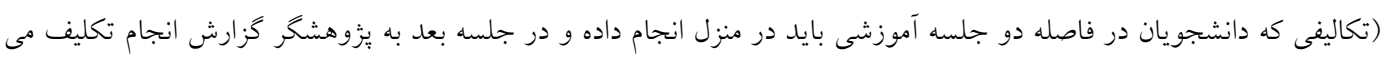

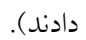

سوم آشنايى با خصوصيات افراد داراى خود- شفتتورزى، شفقت نسبت به ديخران، يرورش احساس گرمى و مهربانى نسبت به خود،

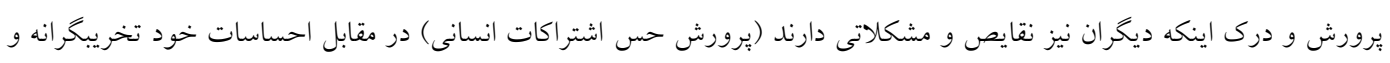
شرم، آموزش همدردى؛ تعريف اينكه همدردى جيست؟ وقتى همدردى مى كنيم تجه مى كنيم و اينكه ديخران وقتى همدردى مى كنند

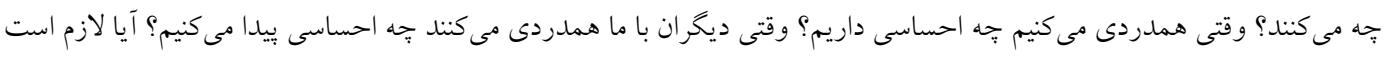

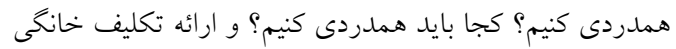

جهارم مرور تمرين جلسه قبل، ترغيب آزمودنى ها به خودشناسى، شناسايى و كاربرد تمرينهاى برورش ذهن مشفقانه، ارزش خود- شفقت

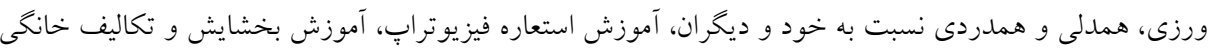

ينجم مرور تمرين جلسه قبل، آشنايى و كاربرد تمرينهاى يرورش ذهن شفقتانه، بخشش، آموزش درباره يذيرش اشتباهات و بخشيدن خود

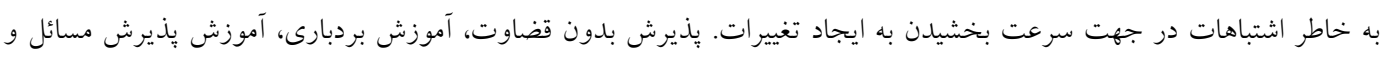

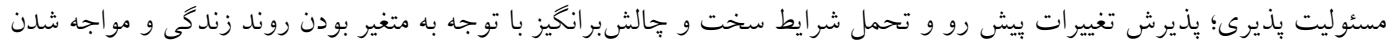

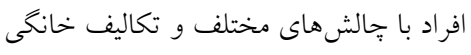


ششم مرور تمرين جلسه قبل، تمرين عملى ايجاد تصاوير شفقتانه، آموزش سبكها و روشهاى ابراز شفقت (شفقت كلامى، شفقت عملى، ونق

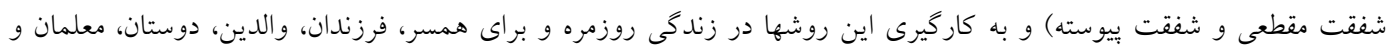

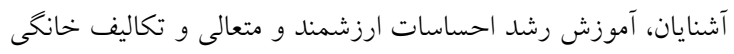

هفتم م مرور تمرين جلسه قبل، آموزش نوشتن نامهاى مشفقانه براى خود و ديخران، تمرين خشم و خود- شفقتورزى، تمرين ترس از ازئ

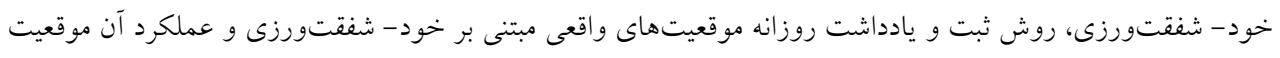

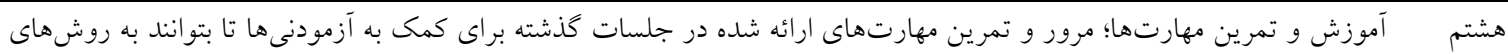

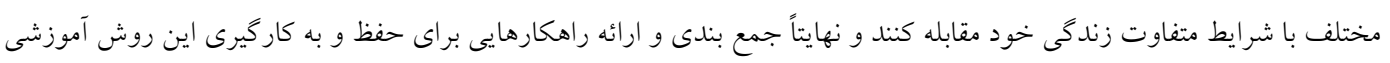

در زندكى روزمره

محتواى ابزار توسط ينج نفر از اساتيد يرستارى دانشكده يرستارى دانشخاه علوم يزشكى ايران مورد سنجش قرار كرفت كه بدين منظور نسخههاى فارسى و انخليسى آن در اختيار اساتيد قرار كرفت و نظرات اصلاحىشان در ابزار اعمال شد. پيايايى ابزار نيز با استفاده از ضريب آلفاى

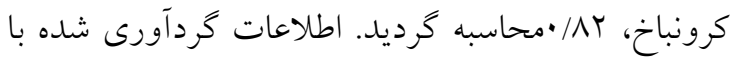
استفاده از آمار توصيفى (فراوانى، درصد، ميانخين و و انحر اف معيار) و استنباطى (آزمون تى زوجى) با استفاده نرم افزار SPSS نسخه 7 1، تحليل شدند (سطح معنىدارى براى آزمون آمارى كمتر از 0 •• • لحاظ شد). به منظور رعايت ملاحظات اخلاقى، بـ از كسب اجازه از كميته

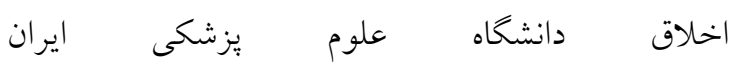

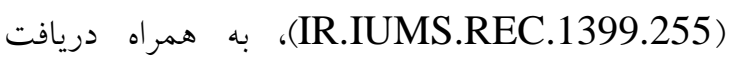
رضايت نامه كتبى از نمونهها، به آنان كفته شد كه اطلاعات مندرج در ابزارها بدون ذكر نام و به صورت محرمانه

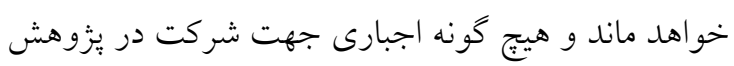

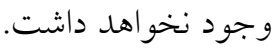

\section{يافتهها}

دانشجويان تحت مطالعه داراى ميانخين سنى 10/•

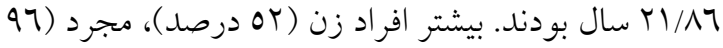
درصد) و سال تحصيلى بيشتر دانشجويان سوم (0N درصد) بود. وضعيت اقتصادى بيشتر دانشجويان ضعيف

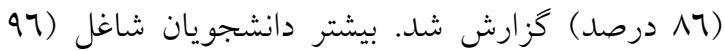
درصد) و مقيم منزل اجارهاى (07 درصد) بودند (جدول

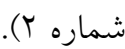

در اين مطالعه جهت گرداورى دادهها از فرم مشخصات فردى جهت سنجش متغيرهاى سن، جنس، وضعيت تأهل، ترم تحصيلى، وضعيت اقتصادى، وضعيت اشتغال و وضعيت اقامت استفاده شد. همجنين از مقياس Positive Affect and Negative (PANAS) Affect Scales استفاده شد. اين ابزار • † كويهاى است كه براى سنجش دو بعد خلقى يعنى عاطفه منفى و عاطفه مثبت در دو خرده

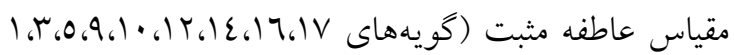

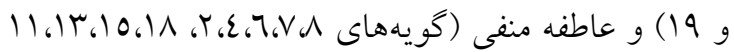
و ·r) طراحى شده است(17). هر خرده مقياس داراى كويه است. گويهها روى يك مقياس 0 درجهاى ليكرت (به هيج وجه، كمى، متوسط، زياد و بسيار زياد به ترتيب از تا ه) رتبه بندى مىشوند. براى اين منظور پِاسخ دهنده بايد يكايك وازگ كان را بخواند. سبس جلوى هر وازه بِاسخ مناسب را علامت بزند و مشخص كند به طور معمول جهه ميزان از هر يك را در V بازه زمانى مشتمل بر لحظه، روز،

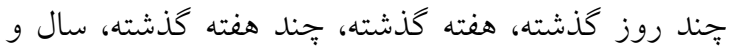
كلى، احساس مى كند. مقياس مذكور شامل وازههايى است كه احساسات و هيجانات متفاوت را توصيف مىكند. دامنه كلى نمرات براى هر خرده مقياس ·ل تا •0 است. دريافت نمرات بالاتر در خرده مقياس عاطفه مثبت، بيانگر وضعيت بهتر و در خرده مقياس عاطفه منفى، بيانخر وضعيت نامطلوب مىباشد. طى مطالعهاى كه با مشاركت يرستاران انجام شد، روايى آن با بهرهگيرى از روش روايى محتوا، مطلوب گزارش شد و يايايى آن با استفاده از ضريب آلفاى كرونباخ VA/ · به دست آمد (9). در اين ثيزوهش نيز روايى 


\begin{tabular}{|c|c|c|c|}
\hline درصد & فراوانى & مشخصات فردى & \\
\hline 17 & $\wedge$ & $r \cdot-r I$ & \\
\hline$\wedge$. & $\varepsilon$. & Tr & سن (سال) \\
\hline$\varepsilon$ & r & بيشتر از Tr & \\
\hline \multirow[t]{3}{*}{$1 \ldots$} & 0. & جمع كل & \\
\hline & & انحر اف معيار 土 ميانخين & \\
\hline & & بيشينه - كمينه & \\
\hline or & $r 7$ & زن & \\
\hline$\varepsilon \wedge$ & $r \varepsilon$ & مرد & جنس \\
\hline $1 \cdots$ & 0. & جمع كل & \\
\hline 97 & $\varepsilon \wedge$ & مجرد & \\
\hline$\varepsilon$ & r & 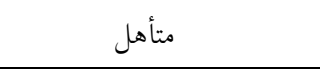 & وضعيت تأهل \\
\hline $1 \cdots$ & 0. & جمع كل & \\
\hline ir & 7 & בوم & \\
\hline $0 \wedge$ & rq & سوم & سال تحصيلى \\
\hline$r$. & 10 & جهارم & \\
\hline $1 \cdots$ & 0. & جمع كل & \\
\hline 17 & $\varepsilon r$ & ضعيف & \\
\hline $1 \varepsilon$ & v & متوسط & وضعيت اقتصادى \\
\hline · & · & خوب & \\
\hline $1 \ldots$ & 0. & جمع كل & \\
\hline 97 & $\varepsilon \wedge$ & شاغل & \\
\hline$\varepsilon$ & r & بيكار & وضعيت اشتغال \\
\hline $1 \ldots$ & 0. & جمع كل & \\
\hline$\varepsilon \varepsilon$ & rr & خوابگاه & \\
\hline 07 & rA & منزل اجارهاى & وضعيت اقامت \\
\hline $1 \cdots$ & 0. & جمع كل & \\
\hline
\end{tabular}

( ) • • بود. بيشترين اندازه اثر عاطفه مثبت در بعد زمانى لحظه (V0/•) و كمترين آن در بعد زمانى جند هفته كذشته

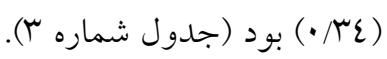

ميانخين و انحر اف معيار نمرات عاطفه منفى در ييش آزمون

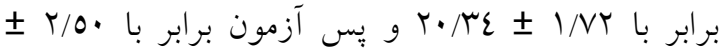
ع/ع/ إبود. نتايج آزمون تى زوجى نشان داد نمره عاطفه

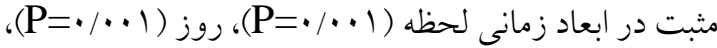

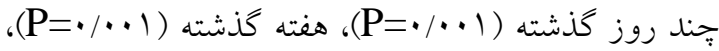

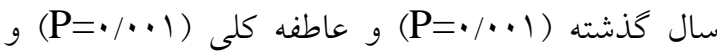

ميانخين و انحراف معيار نمرات عاطفه مثبت در بيش

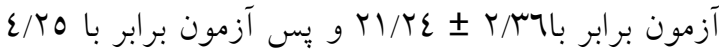

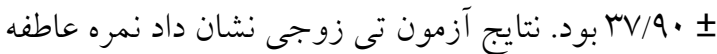

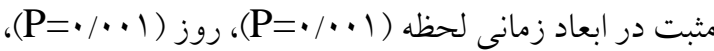

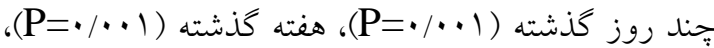

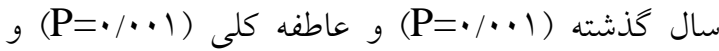

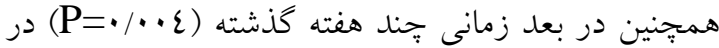
مرحله يس آزمون به صورت معنى دارى نسبت به ييش آزمون افزايش داشته است. اندازه اثر نمره عاطفه مثبت 


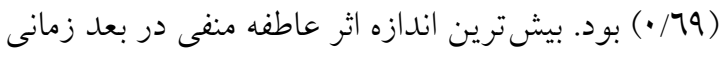

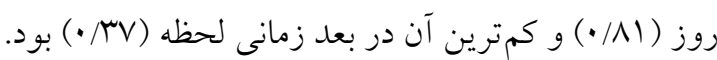

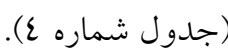

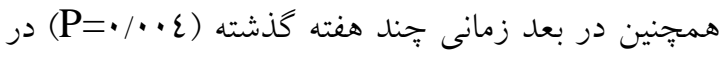

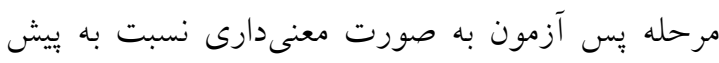

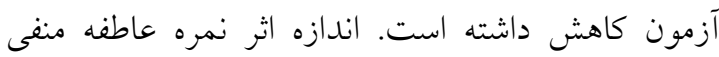

جدول شماره "ّ: ميانكَين و انحراف معيار نمرات عاطفه مثبت در مراحل ييش آزمون و يس آزمون و مقايسه آنها

\begin{tabular}{|c|c|c|c|c|}
\hline اندازه اثر مداخله & نتايج آزمون تى زوجى & انحراف معيار \ ميانگين & مرحله & 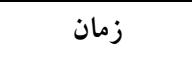 \\
\hline \multirow[t]{2}{*}{$\cdot / \mathrm{VO}$} & $T=-r r / 1 \cdot 0$ & $r \pm r I / r \varepsilon$ & بيش آزمون & لحظه \\
\hline & $\mathrm{df}=\varepsilon q \quad \mathrm{P}=\cdot / \cdot \cdot 1$ & $\varepsilon / \varepsilon \pm r V / r r$ & 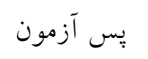 & \\
\hline \multirow[t]{2}{*}{$\cdot / N r$} & $\mathrm{~T}=-r \Gamma / 77 \varepsilon$ & $r / M T \pm r / / 01$ & بيش آزمون & 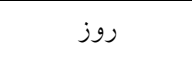 \\
\hline & $\mathrm{df}=\varepsilon q \quad \mathrm{P}=\cdot / \cdot \cdot 1$ & $r / \Lambda \pm r q / r O \Lambda$ & ع بس آزمون & \\
\hline \multirow[t]{2}{*}{$\cdot / 47$} & $T=-r Y / l \cdot r$ & $r / 77 \pm r / / T r$ & بيش آزمون & جند روز كذشته \\
\hline & $\mathrm{P}=\cdot / \cdot \cdot 1$ & $\varepsilon / \varepsilon \varepsilon \pm r V / r r$ & ع بس آزمون & \\
\hline \multirow[t]{2}{*}{$\cdot / \varepsilon V$} & $T=-r r / 79$ & $T / T \varepsilon \pm Y I / T r$ & بيش آزمون & هفته كذشته \\
\hline & $\mathrm{P}=\cdot / \cdot \cdot 1$ & $\varepsilon \pi \Gamma \pm \Gamma V / 00$ & عِس آزمون & \\
\hline \multirow[t]{2}{*}{$\cdot \pi \varepsilon$} & $\mathrm{T}=-\Upsilon \mathrm{Y} / \mathrm{T} r$ & $1 / 99 \pm r 1 / 0 r$ & بيش آزمون & جند هفته كذشته \\
\hline & $\mathrm{df}=\varepsilon q \quad \mathrm{P}=\cdot / \cdots \varepsilon$ & $\cdot / \wedge \pm \varepsilon / \cdot \Lambda$ & عِس آزمون & \\
\hline \multirow[t]{2}{*}{$\cdot / \varepsilon 9$} & $\mathrm{~T}=-\Upsilon O / \Upsilon \mathrm{V}$ & $r / \cdot 9 \pm r 1 / 7 \varepsilon$ & بيش آزمون & سال كذشته \\
\hline & $\mathrm{P}=\cdot / \cdot \cdot 1$ & $r / Q r \pm r V / T$ & 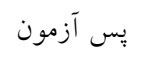 & \\
\hline \multirow[t]{2}{*}{$\cdot / \varepsilon \Lambda$} & $T=-r \varepsilon / 19$ & $T / \mu\urcorner \pm Y I / T \varepsilon$ & ييش آزمون & 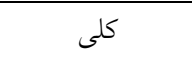 \\
\hline & $\mathrm{df}=\varepsilon q \quad \mathrm{P}=\cdot / \cdot \cdot 1$ & $\varepsilon / r_{0} \pm r V / q$. & 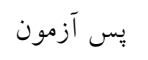 & \\
\hline
\end{tabular}

جدول شماره ع: ميانكَين و انحراف معيار نمرات عاطفه منفى و مقايسه ميانكَينها در مراحل بيش - بِ آز آزمون

\begin{tabular}{|c|c|c|c|c|c|}
\hline اندازه اثر مداخله & زوجى & نتايج آزمو & انحراف معيار \ ميانكين & مرحله ل & \\
\hline \multirow[t]{2}{*}{$\cdot / r V$} & \multicolumn{2}{|c|}{$T=I V / \cdot Y Y$} & $1 / 7 r \pm r \cdot / \mu \Lambda$ & ييش آزمون & لحظه ل لحه \\
\hline & $d f=\varepsilon 9$ & $\mathrm{P}=\cdot / \cdot \cdot 1$ & $r / V \Lambda \pm 1 Y / 7$ & يس آزمون & \\
\hline \multirow[t]{2}{*}{$\cdot / 11$} & \multicolumn{2}{|c|}{$T=1\{/ v q$} & $r / l \pm r \cdot / T \varepsilon$ & يشي آزمون & روز \\
\hline & $\mathrm{df}=\varepsilon 0$ & $\mathrm{P}=\cdot / \cdot \cdot 1$ & $T / N Y \pm \mid r / \varepsilon Y$ & مِس آزمون & \\
\hline \multirow[t]{2}{*}{$\cdot 101$} & \multicolumn{2}{|c|}{$\mathrm{T}=1 / / \backslash \Lambda$} & $1 / N T \pm r \cdot / r \varepsilon$ & بيش آزمون & جند روز كذشته \\
\hline & $\mathrm{df}=\varepsilon 9$ & $\mathrm{P}=\cdot / \cdot \cdot 1$ & $T / T V \pm 1 Y / 17$ & يَس آزمون & \\
\hline \multirow[t]{2}{*}{$\cdot / \varepsilon \wedge$} & \multicolumn{2}{|c|}{$\mathrm{T}=\mid \mathrm{V} / \cdot 9 \Lambda$} & $1 / 17 \pi \pm r \cdot r \mid$ & بيش آزمون & هغته كَشته \\
\hline & $\mathrm{df}=\varepsilon 9$ & $\mathrm{P}=\cdot / \cdot \cdot 1$ & $T / N| \pm| Y / V$ & مِس آزمون & \\
\hline \multirow[t]{2}{*}{$\cdot / \varepsilon \varepsilon$} & \multicolumn{2}{|c|}{$\mathrm{T}=\mid \mathrm{V} / \cdot \mathrm{T}$} & $1 / 7 r \pm r \cdot / r \Lambda$ & بيش آزمون & جند هفته كذشته \\
\hline & $\mathrm{df}=\varepsilon 9$ & $\mathrm{P}=\cdot / \cdot \varepsilon \varepsilon$ & $r / N| \pm| r / N Y$ & يس آزمون & \\
\hline \multirow[t]{2}{*}{$\cdot / 0 r$} & \multicolumn{2}{|c|}{$\mathrm{T}=10 / \mu \Lambda$} & $1 / \nearrow \perp \pm r \cdot / r\urcorner$ & يشي آزمون & سال كذشته \\
\hline & $\mathrm{df}=\varepsilon 9$ & $\mathrm{P}=\cdot / \cdot \cdot 1$ & $r / 11 \pm 1 r / 07$ & يَس آزمون & \\
\hline \multirow[t]{2}{*}{$\cdot / 79$} & \multicolumn{2}{|c|}{$T=\mid \Lambda / \varepsilon \varepsilon Y$} & $1 / V Y \pm r \cdot / r \varepsilon$ & يشي آزمون & كلى \\
\hline & $\mathrm{df}=\varepsilon 9$ & $\mathrm{P}=\cdot \cdot \cdot \cdot 1$ & $T / 0 \pm 1 T / \varepsilon \varepsilon$ & يَس آزمون & \\
\hline
\end{tabular}


مبتنى بر شفقت ورزى دريافت كرده بودند، در مقايسه با

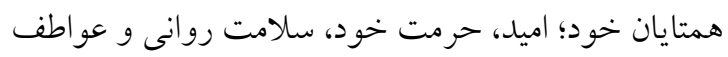

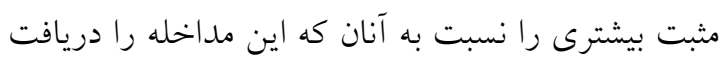

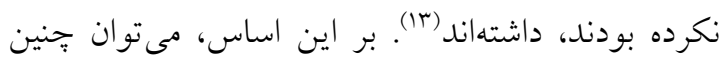

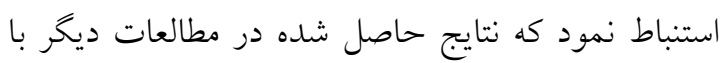
نتايج حاصل شده در مطالعه حاضر از نظر اجراى مداخله خود- شفقتورزى، قرابت دارد. در نهايت بايد اذعان

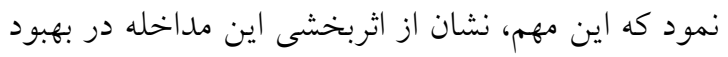
سلامت روانى دارد. با اين حال، مطالعه ميرزايى و شعيرى

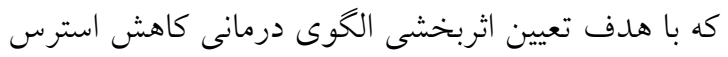
بر اساس ذهن آكاهى بر عواطف مثبت و منفى دانشجويان در شهر زنجان انجام شد، نشان داد كه اجراى مداخله

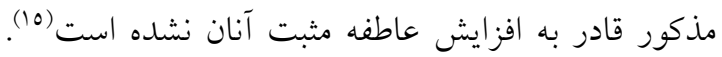
اين بدان معناست كه عاطفه مثبت افراد تحت اجراى

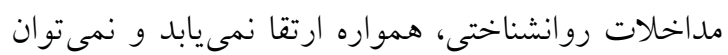
با قطعيت اظهار داشت كه اجراى اين نوع از مداخلات

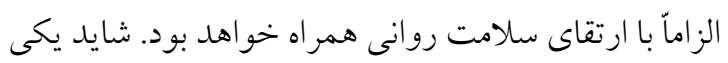
از دلايل ناهمسويى در نتيجه كسب شده ميان مطالعه اخير آنسي

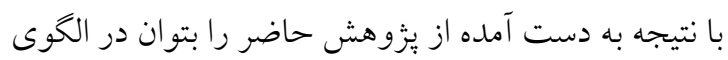

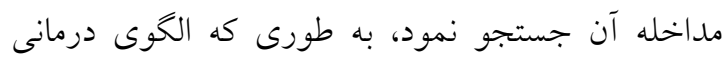

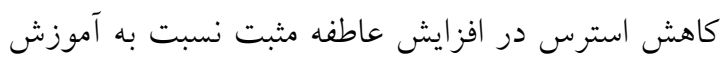

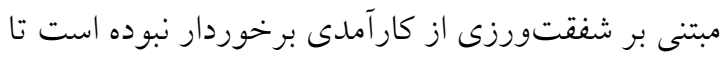

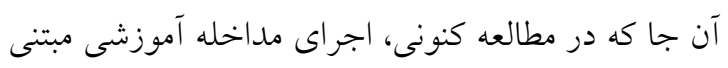
بر شفقتورزى تو انست بر ارتقاى عاطفه مثبت مؤثر باشد.

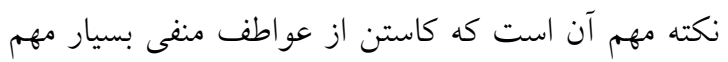

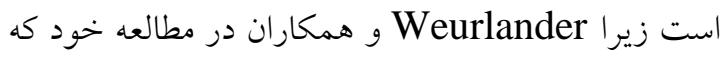
با مشاركت دانشجويان برستارى در سوئد انجام دادند، اذعان داشتهاند كه احساسات و عواطف منفى دانشجويان يرستارى مى توانند دردسرساز شده و مانع از يادكيرىشان شوند (7). اين مطالعه محدوديتهايى نيز داشت. از جمله اين كه روش نمونه گيرى در اين يزوهش غير احتمالى بود بنابراين

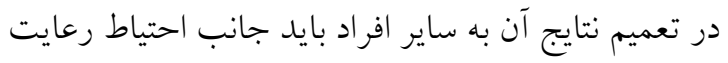

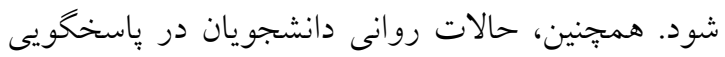

\section{بحث و نتيجهَيرى}

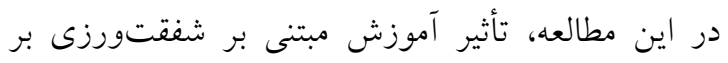

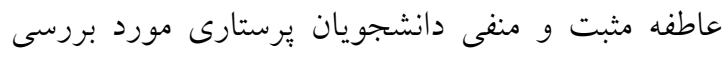

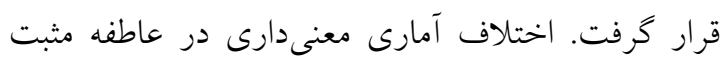
دانشجويان يرستارى، در مراحل بيش آزمون و بـ بس آزمون

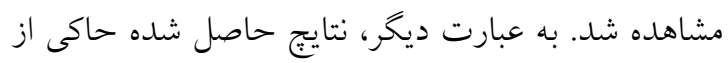

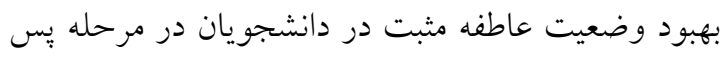

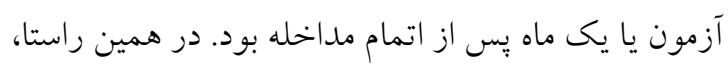

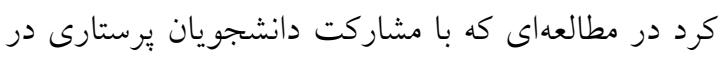
شهر مهاباد انجام داد، بيان داشت كه مىتوان با ارتقاى بـاى

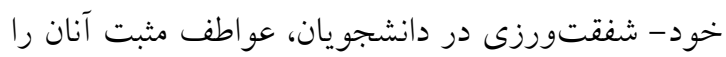
افزايش داد(ع). يززوهشى كه توسط ساريخانى و همكاران

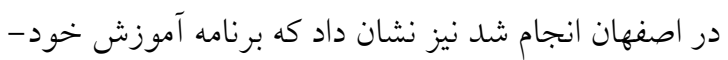
شفتتورزى مىتواند موجب بهبود خود- شفقتورزى

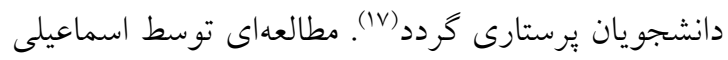
و همكاران با هدف تعيين اثر بخشى شفقت درمانى با برديا

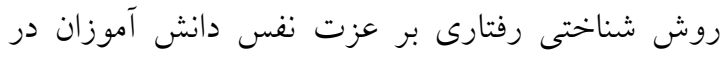

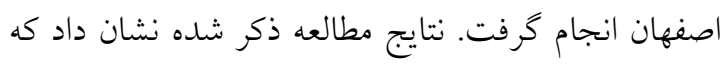
رويكرد مبتنى بر شفقت به طور معنى دارى باعث افزايش

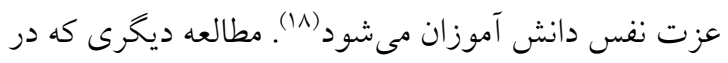

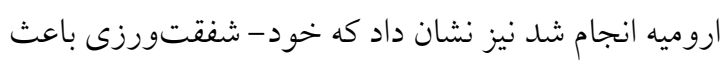

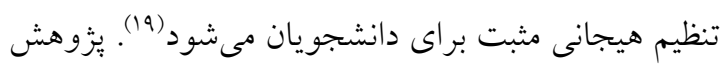

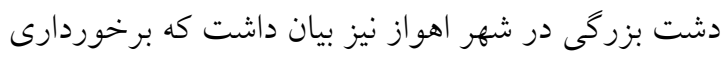

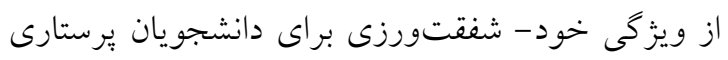

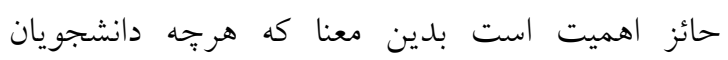
يرستارى از ويزگى خود- شفقتورزى در سطح بالاترى برخوردار باشند، به همان نسبت تعلل ورزى تحصيلى نيز

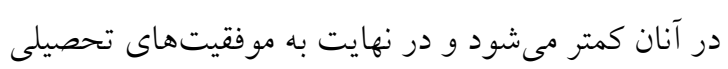
بيشترى دست مى يابند (•r). نتايج به دست آمده از مطالعات مذكور با نتايج حاصل شده دئل در يزوهش حاضر مبنى بر تأثير مثبت مداخله مبتنى بر بر بايج شفقتورزى همسو و هم راستا مىباشد. در همين خصوص، Elaine و Hollins در مطالعه خود كه در ورئاس انخليس انجام شد، بيان داشتند دانشجويانى كه آموزش 
مراكز مشاوره دانشخاههاى علوم يزشكى، جهت مديريت

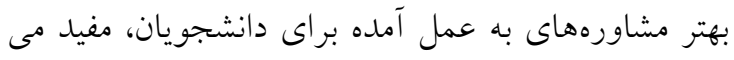

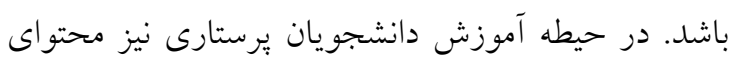

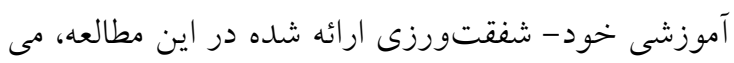
تواند در اختيار اساتيد يرستارى قرار گيرد تا دانشجويان خود را با اين محتوا آشنا نمايند و اين دانشجويان برديان بتوانند تا حد امكان از اين محتوا در طرحهاى مراقبتى خود براى ني مددجويان نيز استفاده نمايند زيرا خود- شفقتورزى مفهومى است كه براى گرووهاى سالم و بيمار جامعه تو أماً

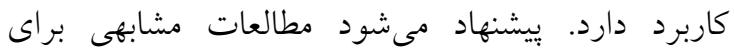
دانشجويان يرستارى شاغل به تحصيل در ساير دانشخاههاى علوم يزشكى كشور و نيز براى ساير رشتهاى علوم

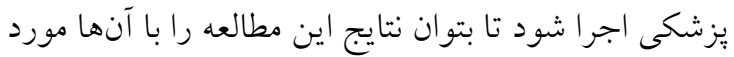
مقايسه قرار داد.

تعارض منافع: هيج گونه تعارض منافع از سوى نويسندگان

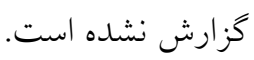

\section{تقدير و تشكر}

اين مطالعه برگرفته از پِيان نامه كارشناسى ارشد روانيرستارى مربوط به نويسنده اول در دانشخاه علوم

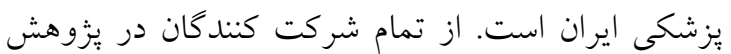
قدردانى مى گردد.

$$
\begin{aligned}
& \text { به كويههاى ابزار مىتوانست مؤثر باشد كه اين محدوديت، }
\end{aligned}
$$

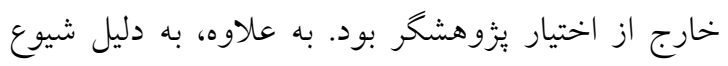

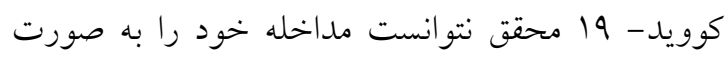

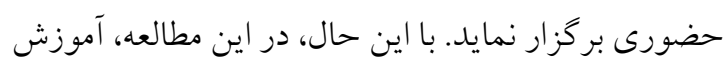

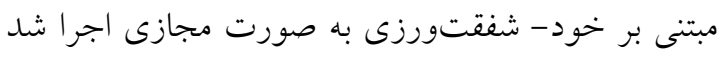

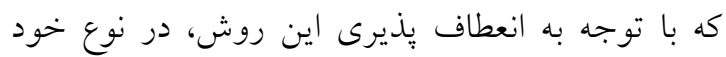

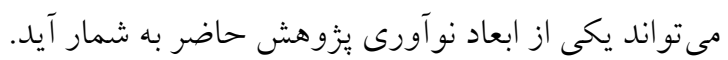

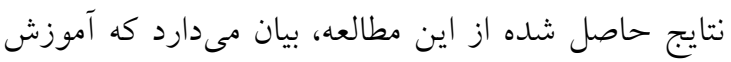

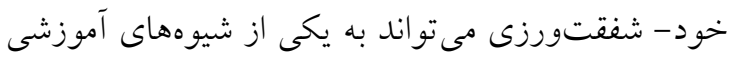

$$
\begin{aligned}
& \text { مفيد و مؤثر در افزايش سلامت روانى دانشجويان تبديل }
\end{aligned}
$$

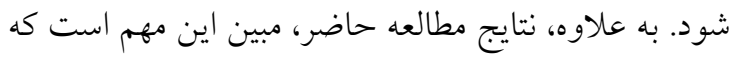

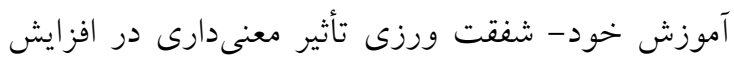

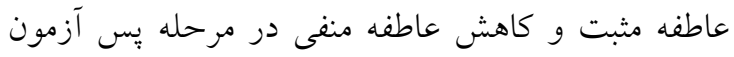

$$
\begin{aligned}
& \text { براى دانشجويان رشته يرستارى مورد يُزوهش داشته است. } \\
& \text { بدين ترتيب يافته هاى مطالعه حاضر مؤيد فرضيه افزايش }
\end{aligned}
$$

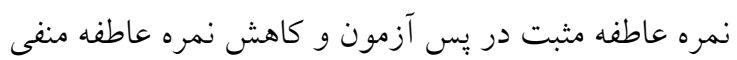

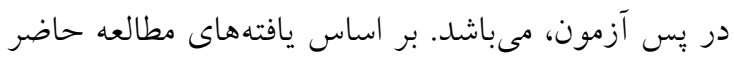

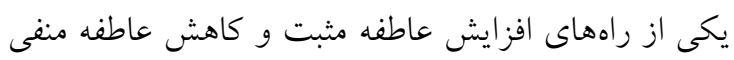

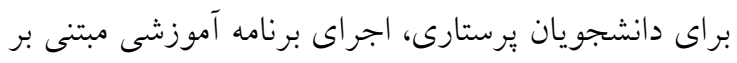

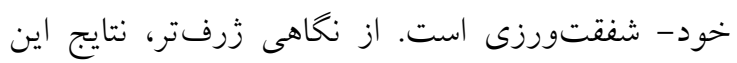

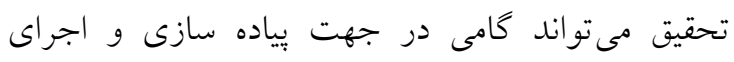

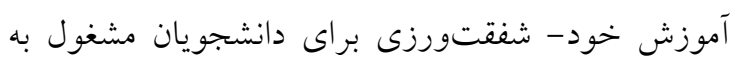

$$
\begin{aligned}
& \text { تحصيل در رشته برستارى در ساير دانشخاههاى علوم }
\end{aligned}
$$

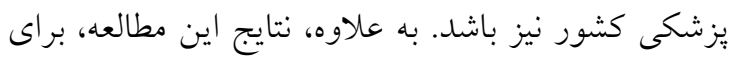

\section{References}

1. Netzer L, Gutentag T, Kim MY, Solak N, Tamir M. Evaluations of emotions: Distinguishing between affective, behavioral and cognitive components. Person Indiv Differ. 2018;135:13-24.

2. Lv J, Li J, Wang C, Zhao P, Bi Y, Zhang X, Yi R, Li X, Bao J. Positive or negative emotion induced by feeding success or failure can affect behaviors, heart rate and immunity of suckling calves. Physiol Behav. 2018;196:185-9.

3. Karreman A, Van Assen MA, Bekker MH. Intensity of positive and negative emotions: Explaining the association between personality and depressive symptoms. Person Indiv Differ. 2013;54(2):214-20.

4. Evers C, Dingemans A, Junghans AF, Boevé A. Feeling bad or feeling good, does emotion affect your consumption of food? A meta-analysis of the experimental evidence. Neurosci Biobehavl Rev. 2018;92:195-208.

5. Gilbert P. The origins and nature of compassion focused therapy. Br J Clin Psychol. 2014 Mar;53(1):6-41. 
6. Weurlander M, Lönn A, Seeberger A, Broberger E, Hult H, Wernerson A. How do medical and nursing students experience emotional challenges during clinical placements?. Int J Med Educ. 2018;9:74.

7. Zhang Y, Luo X, Che X, Duan W. Protective effect of self-compassion to emotional response among students with chronic academic stress. Frontiers in psychology. 2016;7:1802.

8. Barr P. Personality traits, state positive and negative affect, and professional quality of life in neonatal nurses. Journal of Obstetric, Gynecol Neon Nurs. 2018;47(6):771-82.

9. Hashemi J, Jafari E. The Relationship between Positive and Negative Affect and Metacognitive Beliefs and Procrastination Behavior among Nurses. Journal of Health and Care. 2016;18(3):21727. [Persian]

10. Park JJ, Long P, Choe NH, Schallert DL. The contribution of self-compassion and compassion to others to students' emotions and project commitment when experiencing conflict in group projects. Int J Educ Res. 2018;88:20-30.

11. Sun X, Chan DW, Chan LK. Self-compassion and psychological well-being among adolescents in Hong Kong: Exploring gender differences. Person Individ Differ. 2016;101:288-92.

12. Irons $\mathrm{C}$, Lad $\mathrm{S}$. Using compassion focused therapy to work with shame and self-criticism in complex trauma. Australian Clinical Psychologist. 2017;3(1):47-54.

13. Elaine BC, Hollins M. Exploration of a training programme for student therapists that employs Compassionate Mind Training (CMT) to develop compassion for self and others. The Arts in Psychotherapy. 2016;22:5-13.

14. Kurd B. Prediction of nursing students' subjective well-being based on mindfulness and selfcompassion. Iranian Journal of Medical Education. 2016;16(34):272-82. [Persian]

15. Mirzaee E, Shairi MR. Evaluation of effectiveness of mindfulness-based stress reduction model on Positive and Negative Affects and Depression syndrome. Medical Journal of Mashhad University of Medical Sciences. 2018;61(1):864-76. [Persian]

16. Watson D, Clark LA, Tellegen A. Development and validation of brief measures of positive and negative affect: the PANAS scales. J Person Social Psychol. 1988;54(6):1063-70.

17. Khorami ES, Moeini M, Ghamarani A. The effectiveness of self-compassion training: a field Trial. Global Journal of Medicine Researches and Studies. 2016;3(1):15-20.

18. Esmaeili L, Amiri S, Reza Abedi M, Molavi H. The Effect of Acceptance and Commitment Therapy Focused on Self-Compassion on Social Anxiety of Adolescent Girls. Clinical Psychology Studies. 2018;8(30):117-37. [Persian]

19. Kord B, Karimi S. The prediction of emotional regulation based on the students' Self-Compassion and body image. Journal of Educational Psychology Studies. 2017;14(28):207-30. [Persian]

20. Dasht Bozorgi Z. The relationship between Persecution and perfectionism with Academic achievement and Burnout in medical students. Education Strategies in Medical Sciences. 2016;9(1):34-41. [Persian] 